
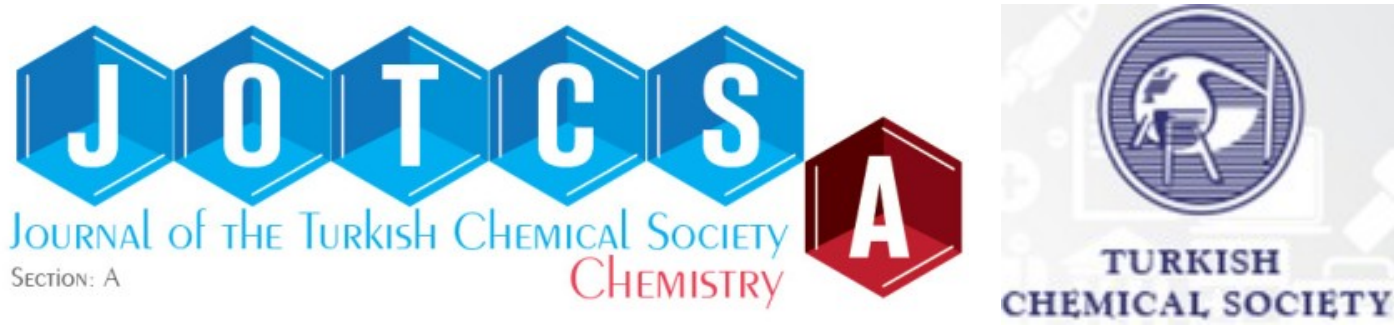

\title{
Optimization and Selection of Mobile Phase for the Determination of Multiple Pesticide Standards Using Liquid Chromatography-Tandem Mass Spectrometry
}

\author{
Abubakar Lawal ${ }^{1,2^{*}} \triangle D_{\text {and Richard Chee Seng Wong }}{ }^{1}$ \\ ${ }^{1}$ Department of Chemistry, University of Malaya, Kuala Lumpur, Malaysia. \\ ${ }^{2}$ Department of Pure and Industrial Chemistry, Umaru Musa Yar'adua University Katsina, Nigeria.
}

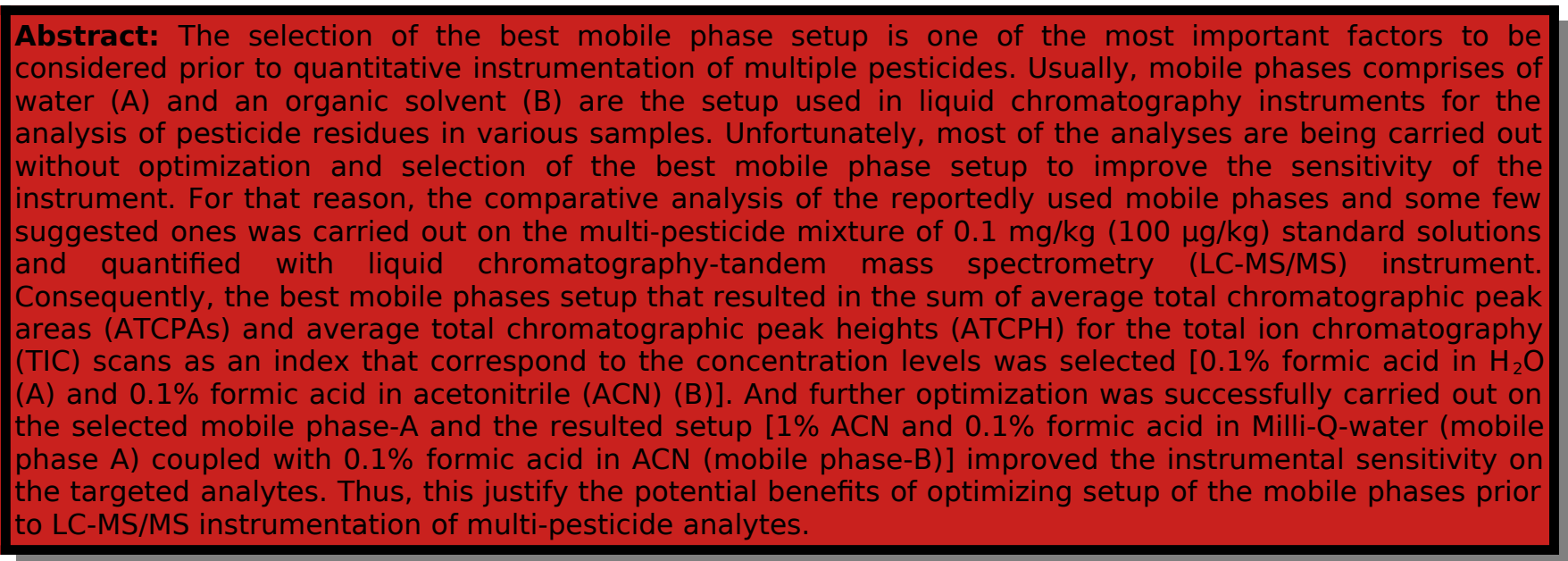

Keywords: Mobile phase, Analysis of multi-pesticide residues, Liquid chromatography-tandem mass spectrometry, Total ion chromatography, Total chromatographic peak areas.

Submitted: August 10, 2020. Accepted: January 06, 2021.

Cite this: Lawal A, Wong R. Optimization and Selection of Mobile Phase for the Determination of Multiple Pesticide Standards Using Liquid Chromatography-Tandem Mass Spectrometry. JOTCSA. 2021;8(1):263-78.

DOI:

https://doi.org/10.18596/jotcsa.778786.

*Corresponding Author. E-mail: abubakarlawal360@yahoo.com.

\section{INTRODUCTION}

Foods are contaminated through various activities performed by man such as the accidental or intentional discharge of chemicals or waste substances from domestic industrial and agricultural sites into the environment $(1,2)$. However, most of these contaminants are nonbiodegradable, which can be easily transferred from the ground surface to the underground water because of their ability in dissolving sparingly in water $(3,4)$. At the long run, the contaminants pollute the foods through their respective circulatory movements in the environment (5). The contaminants include inorganic matters such as heavy metals (6-8), as well as organic chemicals such as heat-generated compounds [polycyclic aromatic hydrocarbons (PAHs) and acrylamide)] (9), organic polymers (bromodiphenyl ethers, chlorobiphenyls, chlorodibenzodioxins, chlorodibenzofurans, etc), mycotoxins (aflatoxins), perfluoroalkyl acids (10-12). Other contaminants with emerge-concerns include phthalates, bisphenol A, alkylphenols (13), phytosterols, estrogens, phytoestrogens (14), pharmaceuticals/veterinary drugs, synthetic dyes and pesticides (15-18).

Advantageously, pesticides have been used in domestic and agricultural practices for decades increasing the gross domestic products (GDP) of 
many countries around the globe. But their dangers in handling and excessive usage have been the issues of concern due to their residual accumulations in food chain resulting in many health problems that include cancers, etc. However, there are challenges experienced in the determination of multiple residue of pesticide analytes in food samples. These could be due to extensive ranges of their chemical properties such as neutral, acidic and basic (19), vapor pressure/Henry's law constant (20), solubility (21), partition coefficient in octanol/water $(\log P)(22)$ and acid dissociation constant $\left(\mathrm{pK}_{\mathrm{a}}\right)$ (23). Besides, the analytical samples also play challenging roles for pesticides extraction during sample preparation because of their features that include non-polar, polar, fatty and waxy samples $(24,25)$.

Even though the conventional methods such as liquid-liquid extraction (LLE), liquid-phase microextraction (LPME) as well as solid phase extraction (SPE) techniques were previously used as the sample preparation methods for the multiple pesticides analysis (16), they possess poor efficiency and selectivity of the targeted, which were their major drawbacks (26). Also, many detectors and quantification instruments were used previously for the analyses of multiple pesticide residues (26). These instruments include the gas chromatographyatomic emission detector (GC-AED) (27) and the high performance liquid chromatography (HPLC) (28). Other instruments include gas chromatography-tandem mass spectrometry (GCMS/MS) (29) and liquid chromatography-tandem mass spectrometry (LC-MS/MS) (30). Unfortunately, the poor sensitivity of these instruments is their major setbacks. Fortunately, the shortcomings of the conventional sample preparation techniques and that of the detecting and quantifying instruments could be corrected through optimization such as the use of response surface methodology (RSM) (26, 31).
Accordingly, these compel food safety analysts to improve better ways of analyzing multi-pesticide residues in food samples through effective sample preparations and instrumentation techniques. For instance, RSM optimization of the instrumental parameters for LC-MS/MS (advanced) instrument such as the setup of the mobile phases could provide better results of pesticides determination at the lower concentration levels.

Usually, mobile phases comprise of Milli-Q-water (A) and an organic solvent (B) setup are used in the liquid chromatography instruments for the analyses of pesticide residues in various samples of food materials $(26,32,33)$. In fact, the organic solvents such as acetonitrile (ACN) and methanol are significantly used in the reverse-phase of liquid chromatography (LC) due to their excellent compatibility (34).

Thus, the aim of this research is to comparatively study the most recently used (reported) setup of mobile phases and some few suggested ones (Table 2 ). The best mobile phases setup that provided highest average total chromatographic peak area (ATCPA) as an index that correspond to the concentration of analytes in the multi-pesticide mixture of standard solutions was selected after the LC-MS/MS instrumentation.

However, the multi-pesticides mixture of standard solutions of Dursban, Diazinon, Thiamethoxam, Metalaxyl, Thiobencarb, Baycarb, Carbaryl and Propamocarb (Figure 1) were analyzed for the purpose of the mobile phase optimization.

It is, therefore, hoped that the result of this study would serve as a reference guide for the future studies, and the optimized mobile phase setup would be routinely used in LC-MS/MS for the determination of multiple pesticide residues in various food samples. 
Table 1: Auto-tuning and Mass-Hunter optimization results of the instrument using the multi-pesticides mixture of standard solutions

\begin{tabular}{|c|c|c|c|c|c|c|c|c|c|}
\hline Pesticide & MF & MIM & TOP & $\mathrm{COC}$ & IM (ESI) & PI & $\mathrm{MRM}_{1} / \mathrm{MRM}_{2}$ & $\mathrm{CE}_{1} / \mathrm{CE}_{2}$ & ART \\
\hline Dursban (Chlorpyrifos) & $\mathrm{C}_{9} \mathrm{H}_{11} \mathrm{Cl}_{3} \mathrm{NO}_{3} \mathrm{PS}$ & 349 & $\begin{array}{l}\text { Insecticide \& } \\
\text { Nematicide }\end{array}$ & Organophosphorus & {$[\mathrm{M}+\mathrm{H}]^{+}$} & 350 & 96.8/197.9 & $34 / 22$ & 11.36 \\
\hline Diazinon & $\mathrm{C}_{12} \mathrm{H}_{21} \mathrm{~N}_{2} \mathrm{O}_{3} \mathrm{PS}$ & 304 & Insecticide & Organophosphorus & {$[\mathrm{M}+\mathrm{H}]^{+}$} & 305 & 96.9/169.1 & $42 / 22$ & 10.22 \\
\hline Thiamethoxam & $\mathrm{C}_{8} \mathrm{H}_{10} \mathrm{ClN}_{5} \mathrm{O}_{3} \mathrm{~S}$ & 292 & Insecticide & Neonicotinoid & {$[\mathrm{M}+\mathrm{H}]^{+}$} & 292 & $132 / 211$ & $26 / 10$ & 2.68 \\
\hline Metalaxyl & $\mathrm{C}_{15} \mathrm{H}_{21} \mathrm{NO}_{4}$ & 279 & Fungicide & Xylylalanine & {$[\mathrm{M}+\mathrm{H}]^{+}$} & 280 & $160.1 / 220.1$ & $26 / 10$ & 7.33 \\
\hline Thiobencarb & $\mathrm{C}_{12} \mathrm{H}_{16} \mathrm{ClNOS}$ & 257 & Herbicide & Thiocarbamate & {$[\mathrm{M}+\mathrm{H}]^{+}$} & 258 & $89.1 / 125$ & $54 / 26$ & 10.34 \\
\hline Baycarb (Fenobucarb) & $\mathrm{C}_{12} \mathrm{H}_{17} \mathrm{NO}_{2}$ & 207 & Insecticide & Carbamate & {$[\mathrm{M}+\mathrm{H}]^{+}$} & 208 & $77 / 95$ & $42 / 10$ & 8.34 \\
\hline Carbaryl & $\mathrm{C}_{12} \mathrm{H}_{11} \mathrm{NO}_{2}$ & 201 & $\begin{array}{l}\text { Insecticide \& } \\
\text { Nematicide }\end{array}$ & $\begin{array}{l}\text { N-Methyl } \\
\text { Carbamate }\end{array}$ & {$[\mathrm{M}+\mathrm{H}]^{+}$} & 202 & $127.1 / 145$ & $30 / 6$ & 7.16 \\
\hline Propamocarb & $\mathrm{C}_{9} \mathrm{H}_{20} \mathrm{~N}_{2} \mathrm{O}_{2}$ & 188 & Fungicide & Other Carbamate & {$[\mathrm{M}+\mathrm{H}]^{+}$} & 189 & 74/102.1 & $26 / 14$ & 1.36 \\
\hline
\end{tabular}

ionization; PI, precursor ion (m/z); MRM, multiple reactions monitoring; CE, collision energy (eV); ART, average retention time (min) 


\begin{tabular}{|c|c|c|c|}
\hline & References & Water (A) & Organic Mobile Phase (B) \\
\hline 1. & $1^{\text {st }}$ suggested mobile phase & $A$ & $\mathrm{ACN}$ \\
\hline 2. & $\begin{array}{l}\text { Rajski, Lozano (35), Pérez- } \\
\text { Ortega, Gilbert-López (54) }\end{array}$ & $A+0.1 \% F A$ & $\mathrm{ACN}$ \\
\hline 3. & $\begin{array}{c}\text {, Economou, Botitsi (56) and } \\
\text { Lucas (57) }\end{array}$ & $A+0.1 \% F A$ & $\mathrm{ACN}+0.1 \% \mathrm{FA}$ \\
\hline 4. & Vázquez, Lozano (36) & $A+0.1 \% F A$ & $\mathrm{ACN}+0.1 \% \mathrm{FA}+5 \% \mathrm{~A}$ \\
\hline 5. & $2^{\text {nd }}$ suggested mobile phase & $A$ & $\mathrm{MeOH}$ \\
\hline 6. & Golge and Kabak (58) & $A+5 \mathrm{mM} \mathrm{AF}$ & $\mathrm{MeOH}+5 \mathrm{mM} \mathrm{AF}$ \\
\hline 7. & Zanella, Munaretto (43) & $\begin{array}{c}\mathrm{A}+2 \% \mathrm{MeOH}+ \\
0.1 \% \mathrm{FA}+5 \mathrm{mM} \mathrm{AF}\end{array}$ & $\begin{array}{c}\mathrm{MeOH}+0.1 \% \mathrm{FA}+5 \mathrm{mM} \\
\mathrm{AF}\end{array}$ \\
\hline 8. & $3^{\text {rd }}$ suggested mobile phase & $A$ & $\mathrm{MeOH} / \mathrm{ACN}(1: 1)$ \\
\hline 9. & $4^{\text {th }}$ suggested mobile phase & $\begin{array}{c}\mathrm{A}+5 \mathrm{mM} \mathrm{AF}+ \\
0.1 \% \mathrm{FA}\end{array}$ & $\begin{array}{c}\mathrm{MeOH} / \mathrm{ACN}(1: 1)+0.1 \% \\
\mathrm{FA}+5 \mathrm{mM} \mathrm{AF}\end{array}$ \\
\hline
\end{tabular}




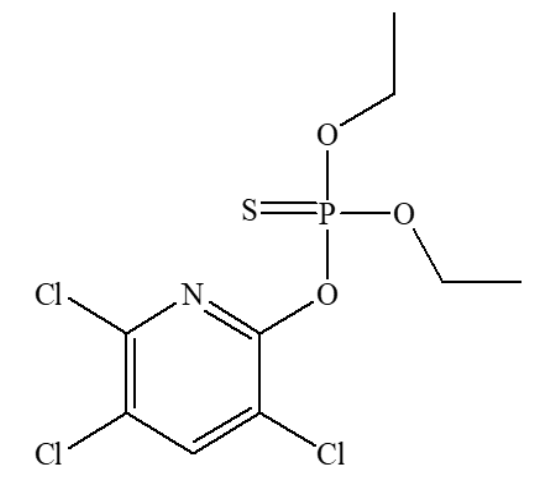

Dursban/Chlorpyrifos (Insecticide/Nematicide)

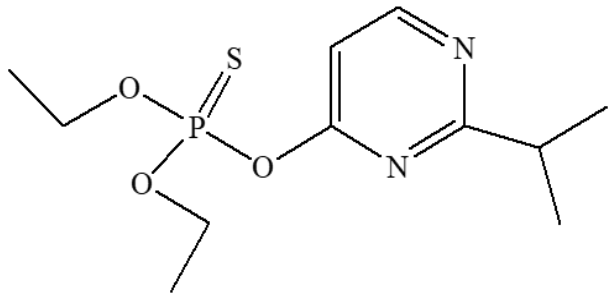

Diazinon (Insecticide)
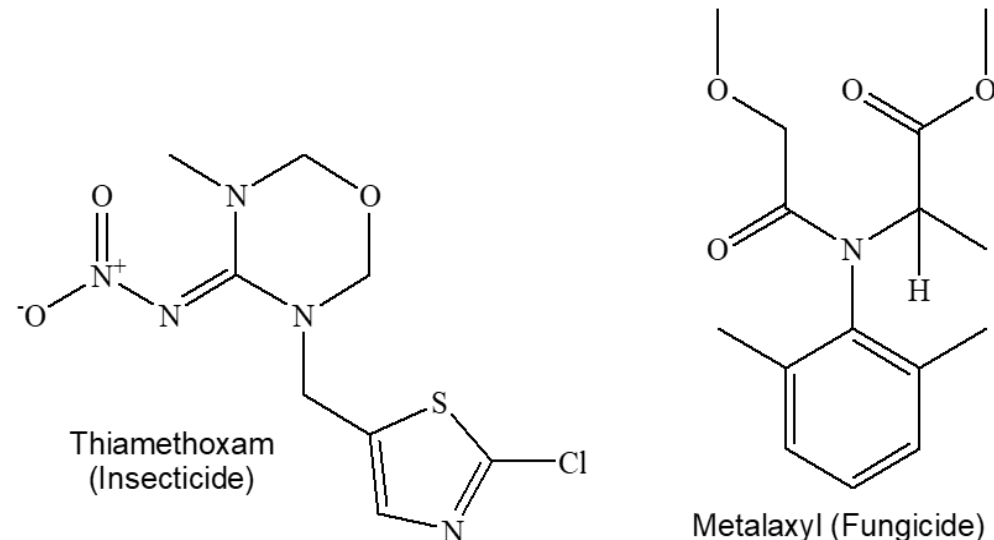

Metalaxyl (Fungicide)

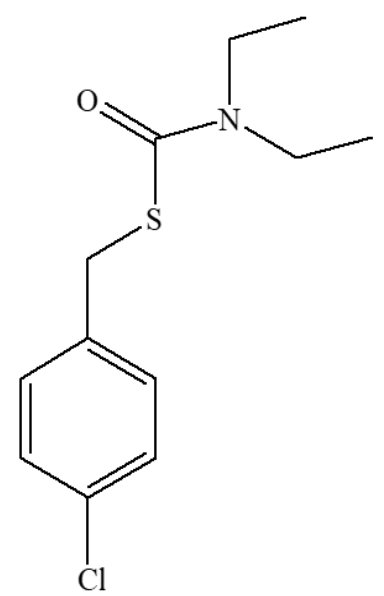

Thiobencarb/Benthiocarb (Herbicide)<smiles>CCC(C)c1ccccc1OC(=O)NC</smiles>

Baycarb/Fenobucarb (Insecticide)<smiles>CNC(=O)Oc1cccc2ccccc12</smiles>

Carbaryl

(Insecticide/Nematicide)

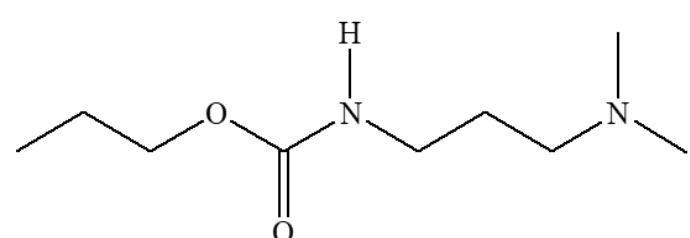

Propamocarb (Fungicide)

Figure 1: Structural formula of the analyzed pesticide residues 


\section{MATERIAL AND METHODS}

The chemicals and reagents such as the stock standard solution $(100 \mathrm{mg} / \mathrm{kg})$ for pesticide Baycarb,

Carbaryl, Diazinon, Dursban, Metalaxyl, $\begin{array}{llr}\text { Propamocarb, } & \text { Thiamethoxam and } \\ \text { Thiobencarbwere were purchased from }\end{array}$ AccuStandard $^{\circledR}$ (New Haven, USA). The LC-MS grade organic solvents that include ACN and methanol were purchased from Merck (Germany). The formic acid was purchased from Fisher Scientific. The Millipore-filtered (deionized) water was obtained using Merck Millipore water purification system (Billerica, USA). While, the apparatus and equipments that include the 100 and $500 \mu \mathrm{L}$ microsyringe were purchased from Agilent (Australia). The $\mathrm{pH}$ meter PB was purchased from Sartorius group (Germany). The HPLC autosampler vials were purchased from Agilent Technologies (USA). The Supelco HPLC column [Ascentis ${ }^{\circledR}$ Express $\mathrm{C}_{18}(5 \mathrm{~cm} \times 2.1 \mathrm{~mm}, 2.7$ $\mu \mathrm{m})$ ] was purchased from Sigma-Aldrich (USA). And the liquid chromatography-tandem mass spectrometry (LC-MS/MS) [triple quadrupole (G6490A) built in Electrospray ESI ( \pm ) MS/MS Sensitivity and Jet stream Technology] instrument was purchased from Agilent (Singapore).

\section{Conditioning of the LC-MS/MS}

The following contributory parameters of the LCMS/MS instrument were setup initially that include; analyte injection volume $(5 \mu \mathrm{L})$, flow rate $(0.1 \mathrm{~mL} /$ min), column temperature $(30 \stackrel{\circ}{ } \mathrm{C})$, gas temperature (200 으), nebulizer gas (45 psi), gas flow (14 L/min), sheath gas temperature (400 ㅇ), capillary voltage $(3000 \mathrm{~V})$, sheath gas flow (11 L/min), and delta ${ }^{(+)}$EMV (200 V). However, these factors contributed in determining optimum fragmentor voltage and the four-fragmentor product ions with their respective retention time (RT) and collision energy (CE) (Table 1). Moreover, the instrumental default settings were further used for the development of the best gradient program runs for the mobile phase-B elution time by adopting and modifying the methods used by Rajski, Lozano (35) and Vázquez, Lozano (36) for analysis of similar multi-pesticide compounds. This results in the best shortest elution time, which provided the best total ion chromatography (TIC) peaks resolution for the LC-MS/MS instrumentation (Figure 2). However, TIC resolution provided an optimum condition for the attainment of higher total chromatographic peak area (TCPA) (37) and mathematically expressed in Equation 1 (38).

Therefore,

$$
T C P A=\sum C P A
$$

Where

TCPA is the total chromatographic peak area and CPA is the chromatographic peak area.
Notably, the best setup of mobile phases were also selected using the initial settings of the instrument. Therefore, the TCPA obtained from LC-MS/MS analysis serves as an index used for estimating the number of target analytes that are present in the analyzed samples (31). It is because of the close similarities range of the resulted peak areas due to the $\log P$ of targeted analytes. Moreover, the peak areas maybe correlated and categorically suitable for multiple pesticides analysis using the LC-MS/MS instrument (39).

\section{Sample Treatment and Methodology}

The stock standard solution of $100 \mu \mathrm{g} / \mathrm{mL}$ that is equivalent to $100 \mathrm{mg} / \mathrm{kg}$ (i.e. $100,000 \mu \mathrm{g} / \mathrm{kg}$ ) or parts per million (ppm) (40) for each pesticide was diluted to 10,1 and $0.1 \mathrm{mg} / \mathrm{kg}(100 \mu \mathrm{g} / \mathrm{kg})$ with appropriate volumes of methanol. The appropriate volumes were calculated using the dilution formula as expressed in Equation 2 (41), separately. Afterward, the prepared working standard solutions were preserved in a refrigerator at 4 으 before carrying out the LC-MS/MS analysis.

$$
C_{1} C_{2}=V_{1} V_{2}
$$

Where

$\mathrm{C}_{1}$ : The concentration of the stock standard solution

$\mathrm{C}_{2}$ : The concentration of the working standard solution

$\mathrm{V}_{1}$ : The volume of the stock standard solution $\mathrm{V}_{2}$ : The volume of the working standard solution.

Meanwhile, the selection of the LC-MS/MS mobile phase was carried out by optimization technique using one factor or variable at a time (OFAT or OVAT) based on the documentation of Sherma (42). However, the multivariate optimization technique was not favorable for the selection because responses for each of the mobile phase is required individually without interaction to estimate the actual effect of the mobile phase setup. Moreover, the two setups of mobile (organic and aqueous) phases are involved with interactive percentage flow of organic/aqueous changes to create an optimum condition of analytes detection. 


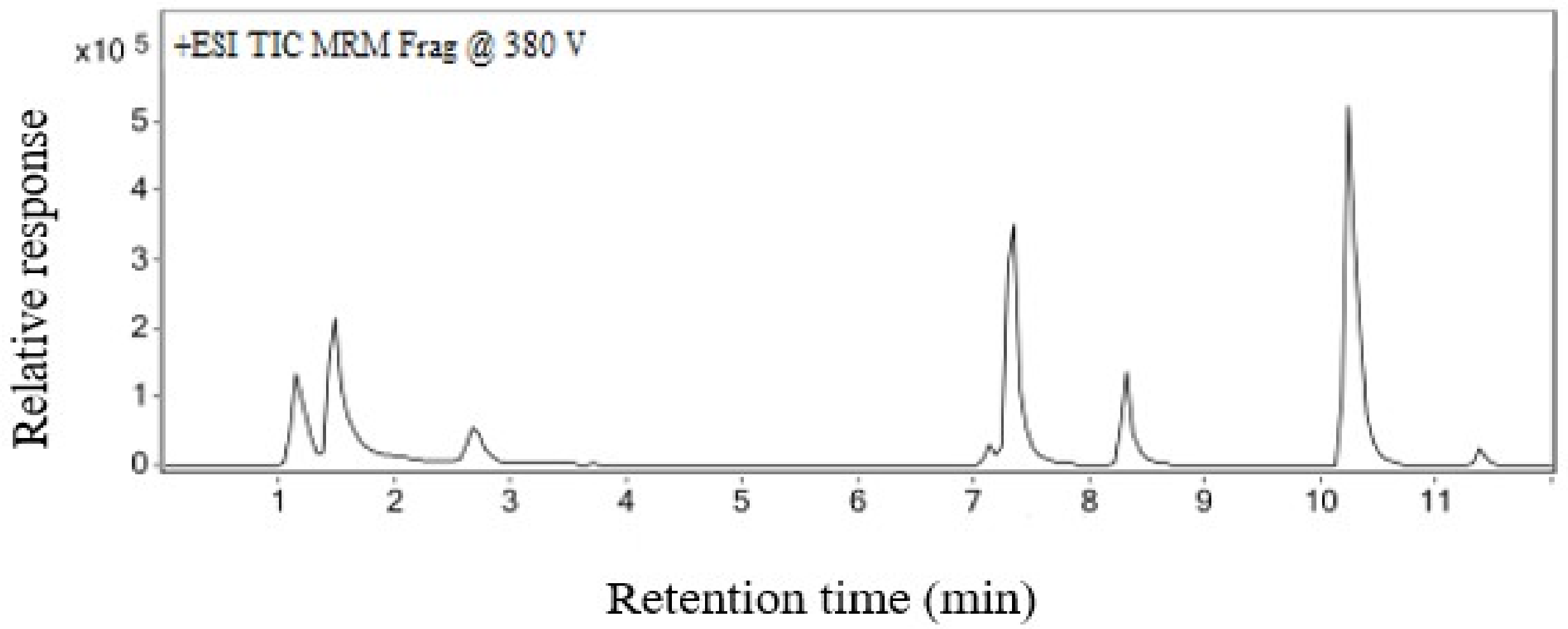

Figure 2: The total ion chromatography (TIC) of the analyzed pesticide standards. 
Table 1: Auto-tuning and Mass-Hunter optimization results of the instrument using the multi-pesticides mixture of standard solutions

\begin{tabular}{|c|c|c|c|c|c|c|c|c|c|}
\hline Pesticide & MF & MIM & TOP & $\mathrm{COC}$ & IM (ESI) & PI & $\mathrm{MRM}_{1} / \mathrm{MRM}_{2}$ & $\mathrm{CE}_{1} / \mathrm{CE}_{2}$ & ART \\
\hline Dursban (Chlorpyrifos) & $\mathrm{C}_{9} \mathrm{H}_{11} \mathrm{Cl}_{3} \mathrm{NO}_{3} \mathrm{PS}$ & 349 & $\begin{array}{l}\text { Insecticide \& } \\
\text { Nematicide }\end{array}$ & Organophosphorus & {$[\mathrm{M}+\mathrm{H}]^{+}$} & 350 & $96.8 / 197.9$ & $34 / 22$ & 11.36 \\
\hline Diazinon & $\mathrm{C}_{12} \mathrm{H}_{21} \mathrm{~N}_{2} \mathrm{O}_{3} \mathrm{PS}$ & 304 & Insecticide & Organophosphorus & {$[\mathrm{M}+\mathrm{H}]^{+}$} & 305 & $96.9 / 169.1$ & $42 / 22$ & 10.22 \\
\hline Thiamethoxam & $\mathrm{C}_{8} \mathrm{H}_{10} \mathrm{CIN}_{5} \mathrm{O}_{3} \mathrm{~S}$ & 292 & Insecticide & Neonicotinoid & {$[\mathrm{M}+\mathrm{H}]^{+}$} & 292 & $132 / 211$ & $26 / 10$ & 2.68 \\
\hline Metalaxyl & $\mathrm{C}_{15} \mathrm{H}_{21} \mathrm{NO}_{4}$ & 279 & Fungicide & Xylylalanine & {$[\mathrm{M}+\mathrm{H}]^{+}$} & 280 & $160.1 / 220.1$ & $26 / 10$ & 7.33 \\
\hline Thiobencarb & $\mathrm{C}_{12} \mathrm{H}_{16} \mathrm{CINOS}$ & 257 & Herbicide & Thiocarbamate & {$[\mathrm{M}+\mathrm{H}]^{+}$} & 258 & $89.1 / 125$ & $54 / 26$ & 10.34 \\
\hline Baycarb (Fenobucarb) & $\mathrm{C}_{12} \mathrm{H}_{17} \mathrm{NO}_{2}$ & 207 & Insecticide & Carbamate & {$[\mathrm{M}+\mathrm{H}]^{+}$} & 208 & $77 / 95$ & $42 / 10$ & 8.34 \\
\hline Carbaryl & $\mathrm{C}_{12} \mathrm{H}_{11} \mathrm{NO}_{2}$ & 201 & $\begin{array}{l}\text { Insecticide \& } \\
\text { Nematicide }\end{array}$ & $\begin{array}{l}\text { N-Methyl } \\
\text { Carbamate }\end{array}$ & {$[\mathrm{M}+\mathrm{H}]^{+}$} & 202 & $127.1 / 145$ & $30 / 6$ & 7.16 \\
\hline Propamocarb & $\mathrm{C}_{9} \mathrm{H}_{20} \mathrm{~N}_{2} \mathrm{O}_{2}$ & 188 & Fungicide & Other Carbamate & {$[\mathrm{M}+\mathrm{H}]^{+}$} & 189 & $74 / 102.1$ & $26 / 14$ & 1.36 \\
\hline
\end{tabular}

PIN, pesticide identity number; MF, molecular formula; MIM, mono-isotopic mass; TOP, type of pesticide; COC, class of chemical; IM, ionization mode; ESI, electrospray ionization; PI, precursor ion (m/z); MRM, multiple reactions monitoring; CE, collision energy (eV); ART, average retention time (min) 
Thus, comparative analysis was carried out on some assumed and selected mobile phases reportedly used for analysis of pesticides in various samples. Experimentally, the comparative analysis was carried out on the multi-pesticide mixture of $0.1 \mathrm{mg} / \mathrm{kg}$ multi-pesticide mixture of standard solutions. Consequently, the TIC of the instrumental runs for each of the mobile phases resulted in chromatographic peak heights (ATCPH), and areas (ATCPAs) as presented in Table 3. Then again, the addition of organic solvent into aqueous mobile phase could provide the optimum condition of $\log P$, which contributes to the attainment of good condition for the multi-pesticide residues analysis in food samples using LC-MS/MS instrument as revealed (43). For this reason, optimization was carried out by serial addition of $A C N$ into the aqueous mobile phase $(0.1 \%$ FA milli-Q-water). Thus, the mobile phase setup that provided the best separation of analytes and the highest TCPA was selected for further optimization by adding 0 , $0.5,1.0,1.5,2.0,2.5,3.0,3.5,4.0,4.5,5.0,7.5$ and $10 \%$ ACN in mobile phase $A$. Moreover, the best $\mathrm{pH}$ solution was selected based on the results of the average TCPA responses of the LC-MS/MS instrument.

\section{RESULTS AND DISCUSSION}

The responses of the screened mobile phases were compared and recorded. The mobile phase setup $[0.1 \%$ formic acid in Milli-Q-water $(A)$ and $0.1 \%$ formic acid in ACN (B)] was the best based on the highest results obtained [ATCPAs \pm standard deviation (STDEV) as well as ATCPH \pm STDEV)] in triplicates as tabulated and illustrated in Table 3 and Figure 3, respectively. This result was also supported by other findings using the mobile phase for pesticides analysis $(44,45)$. Meanwhile, further optimization result of mobile phase-A after addition of $\mathrm{ACN}(0-10 \%)$ revealed that the addition of $1 \%$ ACN into $0.1 \%$ FA Milli-Q-water at an average $\mathrm{pH}$ of $3.50 \pm 0.07$ STDEV (mobile phase A) coupled with $0.1 \%$ FA in ACN at pH $6.56 \pm 0.04$ STDEV (mobile phase-B) provided the highest ATCPA (Table 4).
The results were supported by their respective $\mathrm{pH}$ readings as shown in Table 4 and Figure 4, respectively. Moreover, the retention time ( $\mathrm{min}$ ) of the pesticide analytes were less than the results reported by some literatures such as thiamethoxam, $2.68<2.87$ (46); propamocarb, $1.36<1.47$ (47); carbaryl, $7.16<16.0$ (48); metalaxyl, $7.33<17.90$ (49); thiobencarb $10.34<$ 10.76 (50), and dursban, $11.36<12.30$ (51). But the retention time (min) of baycarb (8.34) and diazinon (10.22) were more than 6.73 (52) and 7.09 (53) respectively. Fortunately, the optimized mobile phase contributes towards shortening the total run time (min) for the multiple pesticides analysis using the LC-MS/MS instrument.

\section{CONCLUSION}

The selection and optimization of the best mobile phase setup was successfully carried out. Eventually, the optimized mobile phase setup [ $1 \%$ ACN and $0.1 \%$ FA in Milli-Q-water (mobile phase-A) coupled with $0.1 \%$ FA in ACN (mobile phase-B)] improved the instrumental sensitivity on the targeted analytes. Thus, this justify the potential benefits of optimizing setup of the mobile phases prior to LC-MS/MS instrumentation of multipesticide analytes. Also, the selected and optimized mobile phase setup could be used for the analysis of other contaminants with similar properties to the analyzed pesticide compounds.

\section{ACKNOWLEDGMENT}

The authors acknowledge the Postgraduate Research Project (IPPP) for supporting this research under the grant no. PG 174-2014B, University of Malaya Kuala Lumpur, Malaysia.

\section{CONFLICT OF INTEREST}

The authors of this research agreed with no conflicts of interest. 
Table 3: The ATCPH and ATCPA Instrumental responses for the selection of mobile phase

\begin{tabular}{|c|c|c|c|c|c|c|}
\hline $\begin{array}{c}\text { Ref } \\
\text { codes }\end{array}$ & References & Water (A) & Organic M/Phase (B) & $\%$ M/Phase B & ATCPH \pm STDEV & ATCPA \pm STDEV \\
\hline$A$ & $1^{\text {st }}$ suggested mobile phase & $A$ & $\mathrm{ACN}$ & 25 & $(361 \pm 2) \times 10^{5}$ & $(47 \pm 3) \times 10^{7}$ \\
\hline $\mathrm{B}$ & $\begin{array}{c}\text { Rajski, Lozano (35), Pérez-Ortega, } \\
\text { Gilbert-López (54) }\end{array}$ & $A+0.1 \% F A$ & $\mathrm{ACN}$ & 30 & $(349 \pm 3) \times 10^{5}$ & $(46 \pm 1) \times 10^{7}$ \\
\hline $\mathrm{C}$ & $\begin{array}{c}\text {, Economou, Botitsi (56) and Lucas } \\
\text { (57) }\end{array}$ & $A+0.1 \% F A$ & $\mathrm{ACN}+0.1 \% \mathrm{FA}$ & 15 & $(50 \pm 1) \times 10^{6}$ & $(72 \pm 9) \times 10^{7}$ \\
\hline $\mathrm{D}$ & Vázquez, Lozano (36) & $\mathrm{A}+0.1 \% \mathrm{FA}$ & $A C N+0.1 \% F A+5 \% A$ & 30 & $(31 \pm 2) \times 10^{6}$ & $(38 \pm 1) \times 10^{7}$ \\
\hline \multirow[t]{2}{*}{$\mathrm{E}$} & $2^{\text {nd }}$ suggested mobile phase & $A$ & $\mathrm{MEOH}$ & 30 & $(17 \pm 1) \times 10^{6}$ & $(23 \pm 2) \times 10^{7}$ \\
\hline & Golge and Kabak (58) & & & & & \\
\hline $\mathrm{F}$ & & $A+5 m M A F$ & $\mathrm{MEOH}+5 \mathrm{mM} \mathrm{AF}$ & 30 & $(26 \pm 2) \times 10^{6}$ & $(30 \pm 1) \times 10^{7}$ \\
\hline G & Zanella, Munaretto (43) & $\begin{array}{c}\mathrm{A}+2 \% \mathrm{MEOH}+ \\
0.1 \% \mathrm{FA}+5 \mathrm{mM} \mathrm{AF}\end{array}$ & $\begin{array}{l}\mathrm{MEOH}+0.1 \% \mathrm{FA}+5 \\
\mathrm{mM} \mathrm{AF}\end{array}$ & 10 & $(58 \pm 3) \times 10^{6}$ & $(60 \pm 7) \times 10^{7}$ \\
\hline $\mathrm{H}$ & $3^{\text {rd }}$ suggested mobile phase & $A$ & MEOH/ACN (1:1) & 30 & $(27 \pm 1) \times 10^{6}$ & $(30 \pm 4) \times 10^{7}$ \\
\hline 1 & $4^{\text {th }}$ suggested mobile phase & $\begin{array}{c}\mathrm{A}+5 \mathrm{mM} \mathrm{AF}+ \\
0.1 \% \mathrm{FA}\end{array}$ & $\begin{array}{l}\text { MEOH/ACN }(1: 1)+ \\
0.1 \% \text { FA }+5 \mathrm{mM} \mathrm{AF}\end{array}$ & 25 & $(36 \pm 5) \times 10^{6}$ & $(32 \pm 3) \times 10^{7}$ \\
\hline
\end{tabular}
acid; STDEV, standard deviation; Ref, reference 


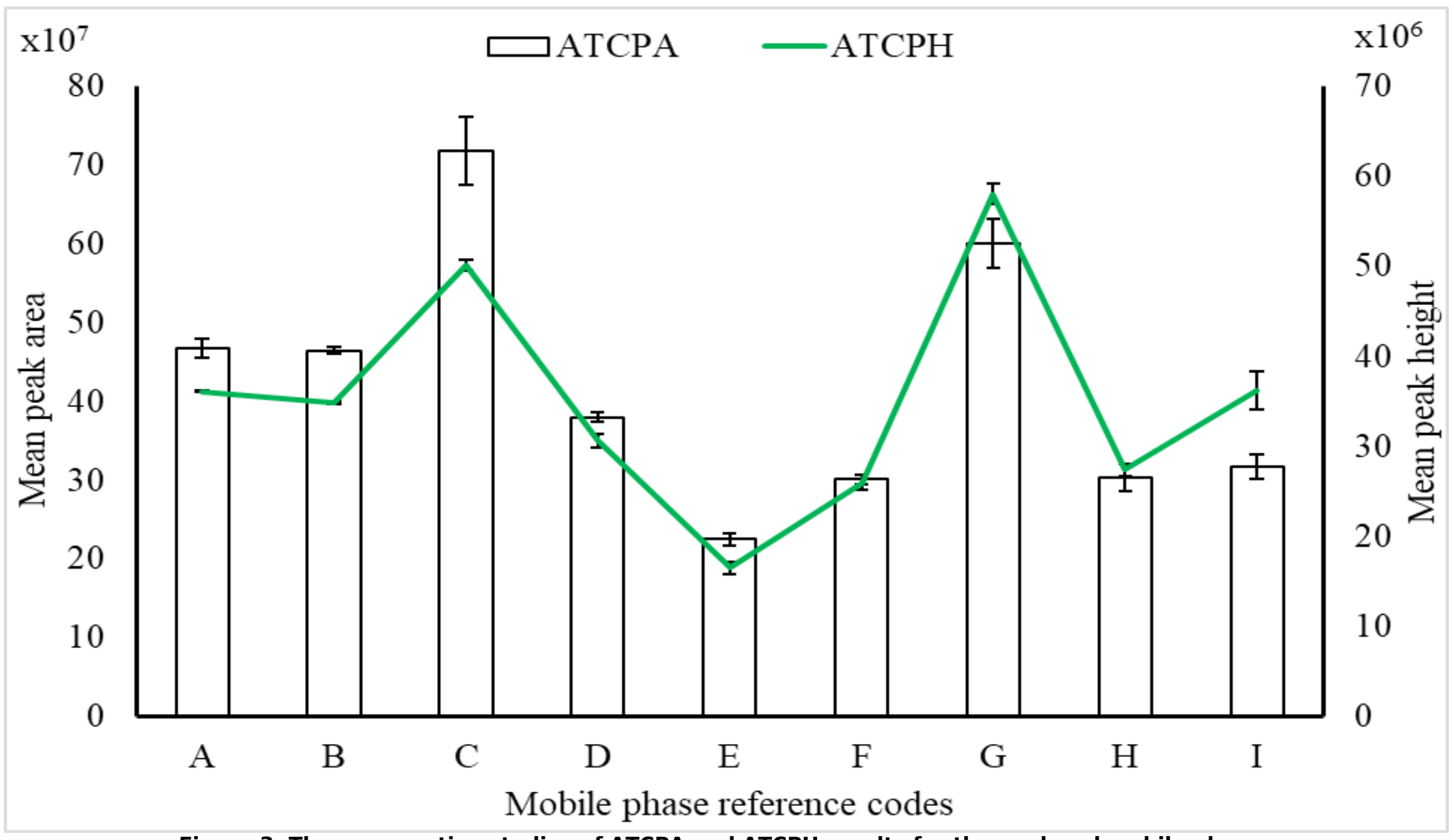

Figure 3: The comparative studies of ATCPA and ATCPH results for the analyzed mobile phases 


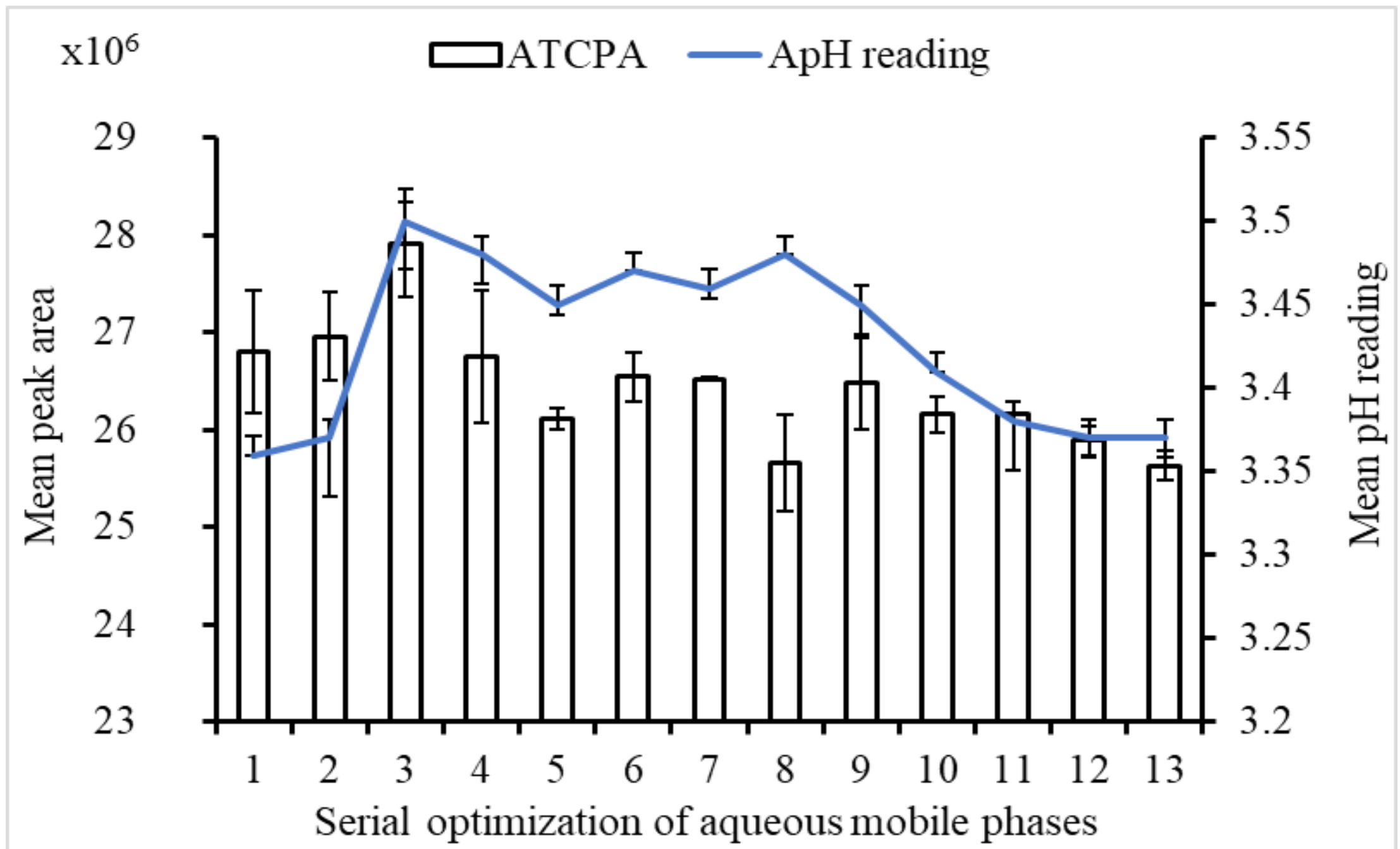

Figure 4: Comparative illustration for the optimization of the selected aqueous mobile phase by ATCPA and ApH readings 
Table 4: The Instrumental responses for the optimization of the selected mobile phase

\begin{tabular}{|c|c|c|c|c|}
\hline Solution & $\%$ ACN in Aqueous Mobile Phase & $\mathrm{ApH}$ reading $\pm \mathrm{STDEV}$ & Organic Mobile Phase & ATCPA \pm STDEV \\
\hline 1 & $\mathrm{H}_{2} \mathrm{O}+0.1 \% \mathrm{FA}+0 \% \mathrm{ACN}$ & $3.36 \pm 0.00$ & $\mathrm{ACN}+0.1 \% \mathrm{FA}$ & $(27 \pm 2) \times 10^{6}$ \\
\hline $\begin{array}{c}2 \\
3 \\
4 \\
5 \\
6 \\
7 \\
8 \\
9 \\
10 \\
11 \\
12 \\
13\end{array}$ & $\begin{array}{l}\mathrm{H}_{2} \mathrm{O}+0.1 \% \mathrm{FA}+0.5 \% \mathrm{ACN} \\
\mathrm{H}_{2} \mathrm{O}+0.1 \% \mathrm{FA}+1.0 \% \mathrm{ACN} \\
\mathrm{H}_{2} \mathrm{O}+0.1 \% \mathrm{FA}+1.5 \% \mathrm{ACN} \\
\mathrm{H}_{2} \mathrm{O}+0.1 \% \mathrm{FA}+2.0 \% \mathrm{ACN} \\
\mathrm{H}_{2} \mathrm{O}+0.1 \% \mathrm{FA}+2.5 \% \mathrm{ACN} \\
\mathrm{H}_{2} \mathrm{O}+0.1 \% \mathrm{FA}+3.0 \% \mathrm{ACN} \\
\mathrm{H}_{2} \mathrm{O}+0.1 \% \mathrm{FA}+3.5 \% \mathrm{ACN} \\
\mathrm{H}_{2} \mathrm{O}+0.1 \% \mathrm{FA}+4.0 \% \mathrm{ACN} \\
\mathrm{H}_{2} \mathrm{O}+0.1 \% \mathrm{FA}+4.5 \% \mathrm{ACN} \\
\mathrm{H}_{2} \mathrm{O}+0.1 \% \mathrm{FA}+5.0 \% \mathrm{ACN} \\
\mathrm{H}_{2} \mathrm{O}+0.1 \% \mathrm{FA}+7.5 \% \mathrm{ACN} \\
\mathrm{H}_{2} \mathrm{O}+0.1 \% \mathrm{FA}+10.0 \% \mathrm{ACN}\end{array}$ & $\begin{array}{l}3.37 \pm 0.08 \\
3.50 \pm 0.07 \\
3.48 \pm 0.04 \\
3.45 \pm 0.01 \\
3.47 \pm 0.00 \\
3.46 \pm 0.01 \\
3.48 \pm 0.00 \\
3.45 \pm 0.04 \\
3.41 \pm 0.00 \\
3.38 \pm 0.07 \\
3.37 \pm 0.03 \\
3.37 \pm 0.03\end{array}$ & $\begin{array}{l}\mathrm{ACN}+0.1 \% \mathrm{FA} \\
\mathrm{ACN}+0.1 \% \mathrm{FA} \\
\mathrm{ACN}+0.1 \% \mathrm{FA} \\
\mathrm{ACN}+0.1 \% \mathrm{FA} \\
\mathrm{ACN}+0.1 \% \mathrm{FA} \\
\mathrm{ACN}+0.1 \% \mathrm{FA} \\
\mathrm{ACN}+0.1 \% \mathrm{FA} \\
\mathrm{ACN}+0.1 \% \mathrm{FA} \\
\mathrm{ACN}+0.1 \% \mathrm{FA} \\
\mathrm{ACN}+0.1 \% \mathrm{FA} \\
\mathrm{ACN}+0.1 \% \mathrm{FA} \\
\mathrm{ACN}+0.1 \% \mathrm{FA}\end{array}$ & $\begin{array}{l}(27 \pm 1) \times 10^{6} \\
(28 \pm 2) \times 10^{6} \\
(27 \pm 2) \times 10^{6} \\
(261 \pm 3) \times 10^{5} \\
(265 \pm 6) \times 10^{5} \\
(2652 \pm 4) \times 10^{4} \\
(26 \pm 1) \times 10^{6} \\
(26 \pm 1) \times 10^{6} \\
(262 \pm 5) \times 10^{5} \\
26 \times 10^{6} \pm 0 \\
(259 \pm 4) \times 10^{5} \\
(256 \pm 4) \times 10^{5}\end{array}$ \\
\hline
\end{tabular}

FA, formic acid; ApH, average pH reading; ATCPA, average total chromatographic peak area; STDEV, standard deviation 


\section{REFERENCES}

1. Chapman PM. Determining when contamination is pollution-weight of evidence determinations for sediments and effluents. Environment International. 2007;33(4):492-501.

2. Prasad KD, Ramteke P. Microbial contamination of important food borne pathogens in the production of an aseptically processed mango drink. Asian Journal of Dairy and Food Research. 2013;32(1):56-64.

3. McCarthy JF, Zachara JM. Subsurface transport of contaminants. Environmental science \& technology. 1989;23(5):496-502.

4. Gong Y, Tang J, Zhao D. Application of iron sulfide particles for groundwater and soil remediation: A review. Water research. 2016;89:309-20.

5. Lake IR, Hooper L, Abdelhamid A, Bentham G, Boxall $A B$, Draper $A$, et al. Climate change and food security: health impacts in developed countries. Environmental Health Perspectives. 2012;120(11):1520.

6. Koki IB, Lawal A, Taqui SN. Source identification and evaluation of surface water quality using factor and discriminant analysis. Bajopas. 2018;11(2):169-75.

7. Baba A, Garba ST, Bello HS. Bioremediation Potential of Immobilized Corynebacterium kutsceri in the Treatment of Tannery Industry Effluent from Challawa Industrial Estate, Kano State, Nigeria. JOTCSA. 2020;7(2):335-50.

8. Lawal A. Comparative analysis on selected bulb species. Sokoto, Nigeria: Usmanu Danfodiyo University; 2011.

9. Mohammed AA, Iniaghe PO, Abu TO, Bello MO, Abdulkadir MD. Source Analysis of Heavy Metals and Polycyclic Aromatic Hydrocarbons from a Popular Dumpsite, Lagos State, Nigeria. JOTCSA. 2020;7(2):489-504.

10. Chan-Hon-Tong A, Charles M-A, Forhan A, Heude $B$, Sirot V. Exposure to food contaminants during pregnancy. Science of the Total Environment. 2013;458:27-35.

11. Alsharif AMA, Tan GH, Choo YM, Lawal A. Liquid Phase Microextraction for Analysis of Mycotoxins in Food Samples: REVIEW. Research Journal of Chemical and Environmental Sciences. 2015;3(6):5-21.

12. Alsharif AMA, Tan GH, Choo Y-M, Lawal A. Efficiency of hollow fiber liquid-phase microextraction chromatography methods in the separation of organic compounds: A review. Journal of Chromatographic Science. 2016:1-14.

13. Meador JP, Yeh A, Young G, Gallagher EP. Contaminants of emerging concern in a large temperate estuary. Environmental Pollution. 2016;213:254-67.

14. Ribeiro AR, Maia A, Santos M, Tiritan ME, Ribeiro CMR. Occurrence of Natural Contaminants of Emerging Concern in the Douro River Estuary, Portugal. Archives of environmental contamination and toxicology. 2016;70(2):361-71.

15. McGrath T, Elliott C, Fodey T. Biosensors for the analysis of microbiological and chemical contaminants in food. Analytical and bioanalytical chemistry. 2012;403(1):75-92

16. Lawal A, Tan GH, Alsharif AMA. Recent Advances in Analysis of Pesticides in Food and Drink Samples Using LPME Techniques Coupled to GC-MS and LC-MS: a Review. Journal of AOAC International. 2016;99(6):1383-94.

17. Lawal A, Wong RCS, Tan GH, Abdulra'uf LB, Alsharif AMA. Recent modifications and validation of QuEChERS-dSPE Coupled to LC-MS and GC-MS instruments for determination of pesticide/agrochemical residues in fruits and vegetables. Journal of chromatographic science. 2018:1-14.

18. Lawal A, Gwaram NS, Suraj Abdulkarim S. Spectrophotometric determination of Tartrazine in some selected beverages: A case study of Katsina town, Nigeria. FUDMA Journal of Sciences. 2020;4(3):685-9.

19. Yang XJ, Du Z, Lin A, Yuan Q, Wan P, Wong C. Simultaneous determination of neutral, basic and acidic pesticides in aquatic environmental matrices by solid-phase extraction and liquid chromatography electrospray ionization mass spectrometry. Anal Methods. 2013;5:2083-92.

20. Jantunen LM, Bidleman TF. Temperature dependent Henry's law constant for technical toxaphene. Chemosphere-Global Change Science. $2000 ; 2(2): 225-31$.

21. Hijosa-Valsero M, Bécares E, Fernández-Aláez $C$, Fernández-Aláez M, Mayo R, Jiménez JJ. Chemical pollution in inland shallow lakes in the Mediterranean region (NW Spain): PAHs, insecticides and herbicides in water and sediments. Science of the Total Environment. 2016;544:797810

22. Mamy L, Patureau D, Barriuso E, Bedos C, Bessac F, Louchart X, et al. Prediction of the Fate of Organic Compounds in the Environment From Their Molecular Properties: A Review. Critical Reviews in 
Environmental Science and Technology. 2015;45:1277-377.

23. Kortum G, Vogel W, Andrussow K. Dissociation constants of organic acids and bases. CRC hand book of chemistry and physics. 2000.

24. Orso D, Martins ML, Donato FF, Rizzetti TM, Kemmerich M, Adaime MB, et al. Multiresidue determination of pesticide residues in honey by modified QuEChERS method and gas chromatography with electron capture detection. Journal of the Brazilian Chemical Society. 2014;25(8):1355-64.

25. Majors RE. QUEChERS-a new technique for multiresidue analysis of pesticides in foods and agricultural samples. Advanstar Communications 131 W First ST, Duluth, MN 55802 USA; 2007.

26. Lawal A, Wong RCS, Tan GH, Abdulra'uf LB. Determination of Pesticide Residues in Fruit and Vegetables by High-Performance Liquid Chromatography-Tandem Mass Spectrometry with Multivariate Response Surface Methodology. Analytical Letters. 2018:1-18.

27. Cook J, Engel M, Wylie P, Quimby B. Multiresidue screening of pesticides in foods using retention time locking, GC-AED, database search, and GC/MS identification. Journal of aoac international. 1998;82(2):313-26.

28. Aulakh J, Malik A, Kaur V, Schmitt-Kopplin P. A Review on solid phase micro extraction-high performance liquid chromatography (SPME-HPLC) analysis of pesticides. Critical Reviews in Analytical Chemistry. 2005;35(1):71-85.

29. Chang C, Luo J, Chen M, Wu K, Dong T, He X, et al. Determination of twenty organophosphorus pesticides in blood serum by gas chromatographytandem mass spectrometry. Analytical Methods. 2016;8(22):4487-96.

30. Qin Y, Chen L, Yang X, Li S, Wang Y, Tang Y, et al. Multi-residue Method for Determination of Selected Neonicotinoid Insecticides in Traditional Chinese Medicine Using Modified Dispersive Solidphase Extraction Combined with Ultra-performance Liquid Chromatography Tandem Mass Spectrometry. Analytical Sciences. 2015;31(8):823-30.

31. Lawal A, Wong RCS, Tan GH, Abdulra'uf LB, Alsharif AMA. Multi-pesticide Residues Determination in Samples of Fruits and Vegetables Using Chemometrics Approach to QuEChERS-dSPE Coupled with Ionic Liquid-Based DLLME and LC-MS/ MS. Chromatographia. 2018;81(5):759-68.

32. Lawal A, Koki IB. Determination of Multi Pesticide Residues in Coconut Water by QuEChERS dSPE Ionic Liquid - Based DLLME Couple with High Performance Liquid Chromatography-Tandem Mass
Spectrometry (LCMS/MS). ChemSearch Journal. 2019;10(1):87-93.

33. Lawal A, Abdulra'uf LB. Chemometrics Approach to QuEChERS-dSPE for Multi-Standard Determination of Pesticides in Blank Samples of Milli-Q-Water Using High-Performance Liquid Chromatography-Tandem Mass Spectrometry (LC-MS/MS). ChemSearch Journal. 2020;11(1):66 - 73.

34. Anastassiades M, Lehotay SJ, Štajnbaher D, Schenck FJ. Fast and easy multiresidue method employing acetonitrile extraction/partitioning and "dispersive solid-phase extraction" for the determination of pesticide residues in produce. Journal of AOAC international. 2003;86(2):412-31.

35. Rajski $Ł$, Lozano A, Uclés A, Ferrer C, FernándezAlba AR. Determination of pesticide residues in high oil vegetal commodities by using various multiresidue methods and clean-ups followed by liquid chromatography tandem mass spectrometry. Journal of Chromatography A. 2013;1304:109-20.

36. Vázquez PP, Lozano $A$, Uclés $S$, Ramos MG, Fernández-Alba A. A sensitive and efficient method for routine pesticide multiresidue analysis in bee pollen samples using gas and liquid chromatography coupled to tandem mass spectrometry. Journal of Chromatography A. 2015;1426:161-73.

37. Scientific C. The theory of HPLC. Chromatographic parameters. e-Learning for the Analytical Chemistry Community, LC/GC, Chromacademy. 2014:1-21.

38. Bramston-Cook R. Peak detection with varian star work station for varian 3800 and 450 gas chromatographs Lotus Consulting 5781 Campo Walk Long Beach, USA: Lotus Flower, Inc. ; 2009. p. 1-24.

39. Lazartigues A, Fratta C, Baudot R, Wiest L, Feidt $C$, Thomas $M$, et al. Multiresidue method for the determination of 13 pesticides in three environmental matrices: water, sediments and fish muscle. Talanta. 2011;85(3):1500-7.

40. Units and concentrations [Internet]. Environmental Protection (Water) Policy 2009. 2018 [cited 24-09-2018]. Available from: https://www.ehp.qld.gov.au/water/monitoring/sampli ng-manual/pdf/data-handling-units-andconcentrations.pdf.

41. How To Find Dilution In Chemistry - Calculate Dilution [Internet]. 2010 [cited 24-09-2018]. Available from: http://www.tutapoint.com/knowledge-center/view/cal culating-dilution/.

42. Sherma J. Recent advances in thin-layer chromatography of pesticides. Journal of AOAC International. 2001;84(4):993-9. 
43. Zanella R, Munaretto JS, Martins ML. Determination of Pesticide Multiresidues in Apple, Pear and Grape using modified QuEChERS and analysis by LC-QTOF-MS. Agilent Technologies, Inc. 2013:1-12.

44. Chen M, Yi Q, Hong J, Zhang L, Lin K, Yuan D. Simultaneous determination of 32 antibiotics and 12 pesticides in sediment using ultrasonic-assisted extraction and high performance liquid chromatography-tandem mass spectrometry. Analytical Methods. 2015;7(5):1896-905.

45. Pastor-Belda $M$, Garrido I, Campillo $N$, Viñas $P$, Hellín $\mathrm{P}$, Flores $\mathrm{P}$, et al. Determination of spirocyclic tetronic/tetramic acid derivatives and neonicotinoid insecticides in fruits and vegetables by liquid chromatography and mass spectrometry after dispersive liquid-liquid microextraction. Food chemistry. 2016;202:389-95.

46. Friedrich MT, Martins ML, Prestes OD, Zanella R. Use of factorial design in the development of multiresidue method for determination of pesticide residues in wheat by liquid chromatography-tandem mass spectrometry. Food Analytical Methods. 2016;9(9):2541-51.

47. Martínez-Domínguez G, Nieto-García AJ, RomeroGonzález R, Frenich AG. Application of QuEChERS based method for the determination of pesticides in nutraceutical products (Camellia sinensis) by liquid chromatography coupled to triple quadrupole tandem mass spectrometry. Food chemistry. 2015;177:182-90.

48. Morais DC, Collins EH, Jardim CH, Fontes ICS. Pesticide determination in sweet peppers using QuEChERS and LC-MS/MS. Food chemistry. 2018;249:77-83.

49. Miliadis G, Tsiantas $P$, Siragakis G. Problems encountered in LC-MS/MS analysis for the determination of pesticide residues in food. Journal of the Hellenic Veterinary Medical Society. 2017;68(4):635-40.

50. Rebelo AM, Dolzan MD, Heller M, Deschamps FC, Abate G, Micke GA, et al. Simultaneous determination of herbicides in rice by QuECHERS and LC-MS/MS using matrix-matched calibration.
Journal of the Brazilian Chemical Society. 2016;27(1):186-93.

51. Bordin AB, Minetto L, Filho IDN, Beal LL, Moura S. Determination of Pesticide Residues in Whole Wheat Flour Using Modified QuEChERS and LC-MS/MS. Food Analytical Methods. 2016:1-9.

52. Zheng W, Park J-A, Zhang D, El-Aty AA, Kim S-K, Cho S-H, et al. Determination of fenobucarb residues in animal and aquatic food products using liquid chromatography-tandem mass spectrometry coupled with a QuEChERS extraction method. Journal of Chromatography B. 2017;1058:1-7.

53. Lopez SH, Lozano A, Sosa A, Hernando MD, Fernandez-Alba AR. Screening of pesticide residues in honeybee wax comb by LC-ESI-MS/MS. A pilot study. Chemosphere 2016;163 44-53.

54. Pérez-Ortega P, Gilbert-López B, García-Reyes JF, Ramos-Martos N, Molina-Díaz A. Generic sample treatment method for simultaneous determination of multiclass pesticides and mycotoxins in wines by liquid chromatography-mass spectrometry. Journal of Chromatography A. 2012;1249:32-40.

55. Núñez $O$, Gallart-Ayala $H$, Ferrer I, Moyano E, Galceran MT. Strategies for the multi-residue analysis of 100 pesticides by liquid chromatography-triple quadrupole mass spectrometry. Journal of Chromatography A. 2012;1249:164-80.

56. Economou A, Botitsi $H$, Antoniou S, Tsipi D. Determination of multi-class pesticides in wines by solid-phase extraction and liquid chromatographytandem mass spectrometry. Journal of Chromatography A. 2009;1216(31):5856-67.

57. Lucas D. Optimizing Sample Preparation for LC/MS/MS of Pesticide Residues in Herbal Teas. Agilent Technologies, Inc, . 2013:1-14.

58. Golge O, Kabak B. Determination of 115 pesticide residues in oranges by high-performance liquid chromatography-triple-quadrupole mass spectrometry in combination with QuEChERS method. Journal of Food Composition and Analysis. 2015;41:86-97. 